\title{
Selecting Amelanchier for Landscape Use from the Native Flora of Nova Scotia and Newfoundland
}

The genus Amelanchier is a diverse group of plants containing $\approx 25$ species, of which seven are native to Atlantic Canada. Few of these have been exploited as landscape plants despite superior ornamental flowers and foliage, and appealing summer fruit. Known locally as Juneberry, serviceberry, shadbush, or Indian plum, the Atlantic amelanchiers have remained relatively obscure, while a western species (Amelanchier alnifolia Nutt., the Saskatoonberry) has become an important fruit crop.

The late R.J. Hilton of Guelph, Ont., initiated a project during 1984 to select superior native amelanchiers from the flora of Nova Scotia and Newfoundland, evaluate them under cultivation, and ultimately name and release the very best taxa for commercialization (Hilton, 1987). Agriculture Canada's Kentville Research Station has played an important role from the project's inception. Cuttings and scion wood of promising selections made by Hilton during 4 years of travel in the region have been propagated and established in two Nova Scotia test sites, in Newfoundland (at Memorial Univ.'s Oxon Pond Botanical Garden), and at the Univ. of Guelph arboretum. Through annual evaluations in Nova Scotia, taxa with excellent landscape potential have been determined.

The seven species of Amelanchier present in Atlantic Canada display a considerable range of size and habit. Moreover, the species crosspollinate readily, leading to many intermediate forms. During field selection, 49 superior representatives of five of the seven species were discovered at diverse locations in Nova Scotia and Newfoundland. The most common species in Nova Scotia and the one that has the greatest representation in test plots is Amelanchier laevis Wieg., a small tree that may attain a mature height of 5 to $12 \mathrm{~m}$. The inflorescence; which is a lax raceme comprising six to 12 flowers, appears in early to midMay in Nova Scotia-about the time that the new foliage is unfolding. At this stage, the

\begin{abstract}
Received fur publication 29 June 1993. Accepted for publication 18 Aug. 1993. Contribution no.2120 of the Kentville Research Station. We gratefully acknowledge the financial support of the Landscape Ontario Horticultural Trades Foundation and the Agriculture Canada New Crop Development Fund. The cost of publishing this paper was defrayed in part by the payment of page charges. Under postal regulations, this paper therefore must be hereby marked advertisement solely to indicate this fact.
\end{abstract}

Front cover: An old specimen of Amelanchier
laeris growing on Nova Scotia farmland. Age and
human activity have taken their toll, but the tree
displays a well-formed crown and abundant spring
flowers.

leaves are an attractive copper/bronze color and contrast strikingly with the pure white or rose-tinted flowers, which may be retained for up to 3 weeks. The small, edible pome fruit ripen in clusters in August; they are about the size of highbush blueberries, with a sugar content typically between $12 \%$ and $20 \%$. In the fall, the foliage turns to many shades, with blood red and deep orange predominating.

Amelanchier bartramiana (Tausch) Roem. is particularly abundant in Newfoundland, where it can grow to a height of $\approx 3 \mathrm{~m}$. In other locations, mature height is often limited to 1.5 $\mathrm{m}$. This small, fastigiate shrub bears flowers that more closely resemble those of apple or pear. The florets are borne in clusters of one to four, and the fruit are somewhat more elongated than those of A. laevis. The low-growing habit of $A$. bartramiana and the rather rare, stoloniferous $A$. fernaldii Wieg. (of which only one specimen was collected) make these plants potentially useful for limited-space landscape sites.

Superior examples of the other two species, A.intermedia Spach and A. wiegandii Nielsen, were collected in both Nova Scotia and Newfoundland. Both commonly grow alongside A. laevis, but differ in habit and leaf and flower form from the latter. Amelanchier intermedia rarely exceeds $5 \mathrm{~m}$ in height, usually with many stems arching downward. In contrast to A. laevis, the foliage is usually well expanded at anthesis. Amelanchier wiegandii (up to $6 \mathrm{~m}$ ) is characterized at anthesis by foliage that remains tightly folded, and later by coarse-toothed leaf margins that make these plants texturally distinct in the landscape.

Atlantic Amelanchier spp. are rated hardy in zone 4a or lower (Sherk and Buckley, 1972) and should be fully hardy in all but the most extreme northern locations. Out of a total of 49 original selections from wild plants, 40 remain in test plots. Secondary selection has focused on superior flowering performance (showy or attractively colored flowers, contrasting flower and foliage colors at anthesis), abundant and high-quality summer fruit, and outstanding fall color. Also emphasized is finding new cultivars with diverse growth habits that range from low-growing branched shrubs to singleand multi-stemmed small trees with potential for specimen or mass planting.

Amelanchier laevis has yielded plants with the most attractive flowers. In most cases, flowers of this species are deep pink in tight bud but open to reveal pure white petals. In two instances (notably the recently released 'R.J. Hilton'), however, the pink pigmentation is retained as the petals unfold. This flower color is novel among the Atlantic amelanchiers and has only been described once before-in an apparent hybrid between A. laevis and A. canadensis [called Amelanchier $\times$ grandiflora Rehd. 'Rubescens' (Rehder, 1956) or $A$. lamarckii 'Rubescens' (Hillier, 1981)]. In other species, flowers have little pigmentation in bud or at anthesis, but in the normally five-petaled A. bartramiana, the potential for doubling appears; in several cases, selected plants display flowers with one or two extra petals in a partial, lower whorl. It seems likely that breeding could enhance this character.

Amelanchiers maybe propagated by a variety of methods. We have had considerable success in grafting scion wood on rootstock of Sorbus aucuparia L. The principle disadvantage of this method is continued and vigorous suckering of the rootstock; cleft grafting on rootstock severed just above the root crown results in less suckering than higher grafts. There remains, however, som uncertainty about the long-term compatibility y of the graft. Success with rooting cuttings is variable between species and clones. Amelanchier wiegandii is easiest to root, but A. laevis selections also root well if current-season tissue is selected just as the shoot begins to harden after the spring flush (Hicklenton, 1988). Greenhouse shading $(\approx 35 \%)$ and fog greatly improve rooting percentages on cuttings dipped for $5 \mathrm{sec}$ in a $75 \%$ water: $25 \%$ ethanol solution of indole-butyric acid (IBA, K-salt; 8- 10,000 $\mathrm{ppm}$ ). Lower IBA concentrations produce neither adequate rooting percentages nor enough roots per cutting (Still and Zanon, 199 1). Forcing budbreak and leaf development on newly rooted cuttings before winter storage is essential for survival. In vitro shoot-tip culture using a modified Murashige and Skoog medium has been successful (Lineberger, 1981).

The first cultivar to be released from the Amelanchier selection and evaluation program was selected in 1991. Since some trees require many years to display their true character and landscape potential, all 40 selections currently in trial plots will continue under evaluation. New Amelanchier sp. cultivars will be introduced via the Canadian Ornamental Plant Foundation (652 Aberdeen Ave., North Bay, Ont., PIB 7H9).

\section{Literature Cited}

Hicklenton, P.R. 1988. Atlantic region nursery research activity. Landscape Trades 10(11):32-35.

Hillier, H.G. 1981. Hilliers manual of trees and shrubs. 5th ed. Van Nostrand Reinhold, New York.

Hilton, R.J. 1987. Why investigate the eastern amelanchiers? Landscape Trades 8(6): 19-21.

Lineberger, RD. 1981. Shoot tip culture of Amelanchier laevis. Ohio Agr. Res. \& Dev. Ctr. Res. Circ. 263: 17-19.

Rehder, A. 1956. Manual of cultivated trees and shrubs hardy in North America exclusive of the subtropical and warmer temperate regions. 2nd ed. Macmillan, New York.

Sherk, L.C. and A.R. Buckley. 1972. Ornamental shrubs for Canada. Agriculture Canada. Ottawa.

Still, S. M.and S. Zanon. 1991. Effects of K-lBAand timing on rooting percentage and root quality of Amelanchier laevis. J. Environ. Hort. 9:86-88.

Peter R. Hicklenton and Kenneth G. Cairns Agriculture Canada Research Station Kentville, N. S., Canada B4N 1J5 